\title{
Quarter milking parameters by lactation in dairy cows
}

\author{
Ramute Mišeikienè ${ }^{*}$, Saulius Tušas \\ Paulius Matusevičius², Sigita Kerzienè ${ }^{3}$
}

\begin{abstract}
${ }^{1}$ Lithuanian University of Health Sciences, Veterinary Academy, Faculty of Animal Science, Institute of Animal Rearing Technologies, Tilžès 18, Kaunas, Lithuania,

${ }^{2}$ Lithuanian University of Health Sciences, Veterinary Academy, Faculty of Animal

Science, Department of Animal Nutrition, L Tilžès 18, Kaunas, Lithuania

${ }^{3}$ Lithuanian University of Health Sciences, Medical academy, Faculty of Medicine,

Department of Physics, Mathematics and Biophysics, A. Mickevičiaus 9, Kaunas, Lithuania

${ }^{*}$ Corresponding author: E-mail: ramute.miseikiene@Ismuni.It
\end{abstract}

\section{Abstract}

The study was conducted on 229 dairy cows in Lithuania. DeLaval milking robots were used for cows' milking. Milk yield (kg), milking duration (min), milk flow ( $\mathrm{kg} / \mathrm{min})$, peak flow rates $(\mathrm{kg} / \mathrm{min})$ by cow lactation in separate udder quarters were analyzed. The statistical analysis of the research data was performed using the data collection and analysis program package Statistical Package for Social Science 22 for Windows, Kolmogorov-Smirnov test and One-Factor Dispersion Analysis (ANOVA) model. Distribution of the udder quarters is very important in the cow milking process. Milk yield from cow front udder quarters was about $4.6 \mathrm{~kg}$ (42.2\%) and from rear udder quarters $6.32 \mathrm{~kg}(57.8 \%)(\mathrm{P}<0.05)$. The milk content in front quarters was significantly lower than in the rear udder quarters in all dairy cows $(P<0.05)$. Cows of the first lactation showed lower milk production per milking in all udder quarters when compared to other lactation cows $(\mathrm{P}<0.05)$. The duration of milking of cows in third and more lactation in front quarters was shorter than that of the first lactation cows $(P<0.005)$. Along the increase in the number of cows' lactations, the milking time in the front quarters decreased. The average milk flow and the peak flow in the first lactation cows were found to be lower than that in older cows $(\mathrm{P}<0.05)$

Key words: automatic milking system, cow, lactation, udder quarter

\section{Introduction}

The health of the cow herd and the quality of milk depends not only on proper hygiene, but also on the choice of milking equipment. Milking robots were developed in order to improve farmer daily routine by reducing labour use and improving cow welfare (Pastell et al., 2006; Kaihilahti et al.,
2007; Jacobs and Siegford, 2012; Castro et al., 2012). An automatic milking system (AMS) allows each cow to be milked at an individual basis and in a place from which the animal can see its herd, which reduces the milking-related stress (Sitkowska et al., 2015). The evaluation of the milking process is necessary to describe the interactions between the milking machine, the milker and the dairy cow. It is 
also related to the efficiency of milking and to the state of udder health. Study of milk flow during the milking provides a useful information for enhancing the efficiency of the milking process and protecting udder health (Sandrucci et al., 2007). A more efficient control system is the fully automated milking, that provides the possibility of milking each udder quarter separately taking into consideration milk yield and milk flow, as well as measuring and registering data at quarter level at each milking (Berglund et al., 2007). This milking system requires a single quarter based milk flow data due to considerable differences in milk yield and milk flow among quarters (Tancin et al., 2006). Quarter milk flow parameters could be useful information for automated monitoring of health problems (Schukken et al., 2003; Tancin et al., 2003). Many studies established that milk yield increases with increasing the lactation number (Vijayakumar, 2017; Arbel et al., 2001), whereby the analysed milking traits came from separate udder quarters (Tancin et al., 2006). However, there were no studies focused on determining the relationship among cows' lactation and milking traits from each quarter. The aim of our study was to analyse milking traits in individual quarters of the udder depending on the cow lactation number.

\section{Materials and methods}

The study was conducted on 229 dairy cows in 2016. Cows were milked with four DeLaval milking robots. The analysed parameters were determined during the milking process at the DelPro herd management program. Cows were milked on average 2.9 times a day. During 30 days, following parameters were analysed: milk yield (kg), milking duration (min), milk electrical conductivity $\mathrm{mS} / \mathrm{cm}$, milk flow (kg/min), peak flow rates $(\mathrm{kg} / \mathrm{min})$ by cow lactation in LF (left front), LR (left rear), RF (right front) and $\mathrm{RR}$ (right rear) udder quarters.

The statistical analysis of the research data was performed using the data collection and the analysis program package SPSS 22.0 (Statistical Package for Social Science 22 for Windows). Using the Kolmogorov-Smirnov test the assumption of the continuity of the variables was verified.

The effect of lactation on characteristics under investigation (Yi) was evaluated by the One-Factor
Dispersion Analysis (ANOVA) model $Y i=\mu+$ Lactation $+e_{i}$.

Differences between lactations were estimated by the post hoc Fisher LSD criterion. Since a statistically significant effect of lactation was found in all investigated traits, the differences between the quarters were evaluated separately for each lactation. For the quarterly differences we calculated the average values of the attributes and their errors and compared those using the Student's test for dependent samples. Differences are statistically significant when $P<0.05$. We evaluated the correlation coefficients of the Pearson linear correlation between different quarters. The linear regression model $Y_{i}=\mu+Y_{j}+Y_{k}+Y_{1}+e_{i j k l}$ evaluated how the property investigated for one quarter depended on the same characteristics of the remaining quarters $\left(Y_{i}, Y_{j}, Y_{k}, Y_{j} ; 1-4\right.$ quarters of the investigative attributes).

\section{Results and discussion}

Distribution of the udder quarters is very important in the cow milking process. The ejection of milk from the separate udder quarters is presented in Figure 1. Milk yield from the cow front udder quarters was about $4.6 \mathrm{~kg}$ (42.2\%) and from rear udder quarters $6.32 \mathrm{~kg}(57.8 \%)(P<0.05)$. Slyžius et al. (2014) and Weiss et al. (2004) found that front quarters produced about $40.0 \%$ and rear quarters about $60.0 \%$ of the total milk yield $(\mathrm{P}<0.001)$ while Tancin et al. (2006) estimated RF and LF quarters produced $22.04 \%$ and $22.23 \%$ of the total milk, whereas RR and LR quarters produced $28.24 \%$ and $27.49 \%$. Milk yield from the right front quarter was $1.8 \%$ or $0.2 \mathrm{~kg}$ more compared with yield from the left front quarter $(P<0.05)$. As described by other authors (Ipema et al., 2008; Antalik et al., 2010) the total milk yield significantly differed between all four quarters within an udder. It depends from what part of the quarters (front or rear) milk is produced (Tančin et al., 2006) as well as the health status of dairy cows. Usually, it is the highest in the RR quarter and lowest in the LF quarter. Our results are consistent with findings that the highest milk yield was determined in the RR quarter of the first and the second lactation cows and the lowest in the LF quarters of all lactation cows. Slyžius et al. (2014) 
obtained on the average $16.78 \%$ more milk from the rear udder quarters than from the front udder quarters $(P<0.001)$. The difference between milk yield from the right side quarters and the left side quarters was determined $0.77 \%(\mathrm{P}<0.001)$. The most milk was produced from the rear right quarter $(29.79 \%)$ while the least milk was produced from the right front udder quarter (20.59\%) (Slyžius et al., 2014). Tancin et al. (2007b) estimated a minimum difference of milk yield between the front and the rear quarters of the udder. About $47 \%$ of the total milk yield came from the front quarters and $53 \%$ from the rear quarters. Other researchers (Bach and Busto, 2005; Berglund et al., 2007) found a $20 \%$ higher milk yield from the rear quarters than from the front quarters.
The amount of cows' milk in different udder quarters depending on lactation is presented in Table 1.

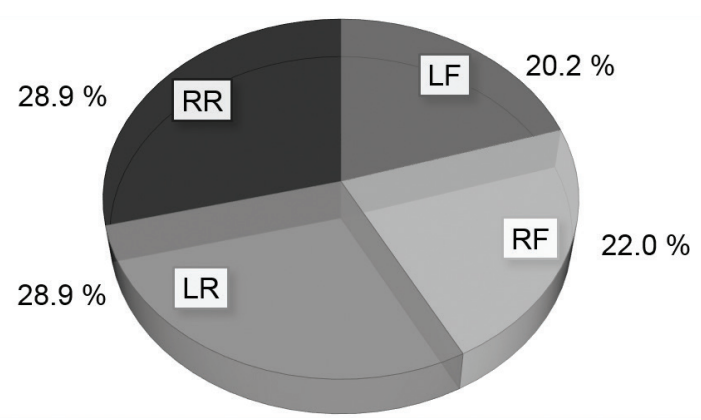

FIGURE 1. Distribution of milk yield in separate udder quarters, \%

TABLE 1. Distribution of the total milk yield in the udder quarters of different lactation cows'

\begin{tabular}{l|l|l|l|l|l}
\hline \multirow{2}{*}{ Lactation } & Number of cows & \multicolumn{4}{l}{ Milk yield from udder quarters } \\
\cline { 3 - 6 } & & LF & RF & LR & RR \\
\hline 1 & 78 & $2.12 \pm 0.05^{\mathrm{a} ; \mathrm{A}}$ & $2.17 \pm 0.05^{\mathrm{a}, \mathrm{A}}$ & $2.63 \pm 0.06^{\mathrm{b} ; \mathrm{A}}$ & $2.68 \pm 0.06^{\mathrm{b} ; \mathrm{A}}$ \\
\hline 2 & 67 & $2.35 \pm 0.06^{\mathrm{a} ; \mathrm{B}}$ & $2.47 \pm 0.08^{\mathrm{b} ; \mathrm{B}}$ & $3.28 \pm 0.07^{\mathrm{c} ; \mathrm{B}}$ & $3.29 \pm 0.10^{\mathrm{c} ; \mathrm{B}}$ \\
\hline $3^{\text {th }}$ and more & 84 & $2.18 \pm 0.05^{\mathrm{a} ; \mathrm{A}}$ & $2.46 \pm 0.05^{\mathrm{b} ; \mathrm{B}}$ & $3.30 \pm 0.06^{\mathrm{c} ; \mathrm{B}}$ & $3.28 \pm 0.06^{\mathrm{c} ; \mathrm{B}}$ \\
\hline
\end{tabular}

a, b, $\mathrm{c}$ - means in the row with different superscripts differed significantly $(P<0.05)$

A, $B$ - means in the column with different superscripts differed significantly $(P<0.05)$

Milk content in front quarters was significantly lower than in rear udder quarters in dairy cows $(P<0.05)$. The milk yield from the first lactation cows in the RR quarter was only $0.56 \mathrm{~kg}$ more than in LF and $0.51 \mathrm{~kg}$ more than in RF quarters $(P<0.05)$. More milk yield from all four quarters was observed in the second lactation dairy cows. The highest increase of milk ( $0.65 \mathrm{~kg}$ ) compared with the first lactation cows was found in LR quarter, while the low increase $(0.23 \mathrm{~kg})$ was determined in the LF quarter. Most of the milk in the second lactation cows produced RR quarter, i.e. $0.94 \mathrm{~kg}$ more than $\mathrm{LF}$ quarter $(\mathrm{P}<0.05)$. The milk content of first lactation cows in the separate quarters was significantly lower $(\mathrm{P}<0.05)$ compared to the second and third lactation cows, except the third and more lactating cows' LF quarter, and from LR quarter these lactations cows $0.67 \mathrm{~kg}$ milk more compared to the first lactation cows $(P<0.05)$. Many researchers found a relationship between the cow lactation and the milk yield. Vijayakumar et al. (2017) found a significant relationship between the milk yield and the lactation number $(\mathrm{P}<0.001)$, with the maximum milk yield occurring in the third lactation cows. There was a significant relationship between the first and the second lactation and milk yield, whereas the maximum milk yield was obtained in the fourth lactation. The milk yield increased gradually from 1 to 3 lactation cows. Cows with more than third lactation exhibited the tendency for the total milk yield to decrease. Rey et al. (1992) reported the total milk yield increase in cows as lactation number from calving increased, but they found a decreasing rate with the lactation number. The highest milk yield was reached by the dairy cows in the third lactation $(8.91 \pm 2.83 \mathrm{~kg})$ and the lowest average total milk yield was detected in the group of dairy cows in the first lactation $(7.03 \pm 1.44 \mathrm{~kg})$. The total milk yield as well as the total milking duration significantly differed between all four quarters within an udder (Antalik et al., 2010; Strapak et al., 2009).

The duration of milking of different lactation cows is given in Table 2. Milking duration of the first 
lactation cows' LF and RF udder quarters was respectively $0.18 \mathrm{~min}$ and 0.38 min longer compared with the milking time of third and more lactating cows $(P<0.05)$.

The milking time of the second lactation cows in LR quarter was 0.34 min. longer than in RF udder quarter $(\mathrm{P}<0.05)$. Milking time of all lactations in the front quarters was significantly shorter than in the rear quarters $(P<0.05)$. Sitkowska et al. (2015) found a positive relationship between the milking duration and the milk yield, but a highly negative relationship was found between the milking duration and the milking speed. Weiss et al. (2004) found the milking time was 1.1 min longer and the milking speed was $0.13 \mathrm{~kg} / \mathrm{min}$ higher in the rear quarters of the cow's udder than in the front quarters. Tancin et al. (2007a) showed that the difference in the milking time between the rear and the front quarters of the udder was $0.6 \mathrm{~min}$, and the difference of the milking speed was $0.14 \mathrm{~kg} / \mathrm{min}$. As reported by Lee and Choudhary (2006), milking duration is negatively correlated with milking speed. The results of Ipema et al. (2008) showed that the milking duration was the longest in the left rear quarters and the shortest in the left front quarters. The mean milk yield and milking duration per quarter per milking were, respectively, $4.10 \mathrm{~kg}$ and $5.73 \mathrm{~min}$. Rear quarters had significantly shorter milking duration than front quarters; this corresponds somewhat with the differences in milk yield (Ipema et al., 2008). Analysis of all experimental cows' results showed front quarters milking time was on average 1.08 min lower than of rear udder quarters $(P<0.05)$. The shortest milking time was established in LF quarter (2.36 min) and the longest in $L R$ udder quarter (3.25 min) $(P<0.05)$.

TABLE 2. Milking duration of different lactation cows

\begin{tabular}{l|l|l|l|l|l}
\hline \multirow{2}{*}{ Lactation number } & \multirow{2}{*}{$\begin{array}{l}\text { Number of } \\
\text { cows }\end{array}$} & \multicolumn{4}{l}{ Milking duration of udder quarters, min } \\
\cline { 3 - 6 } & & LF & RF & LR & RR \\
\hline 1 & 78 & $2.54 \pm 0.06^{\mathrm{a} ; \mathrm{A}}$ & $3.02 \pm 0.07^{\mathrm{a} ; \mathrm{A}}$ & $3.21 \pm 0.07^{\mathrm{b}}$ & $3.18 \pm 0.06^{\mathrm{b}}$ \\
\hline 2 & 67 & $2.43 \pm 0.06^{\mathrm{a}}$ & $2.45 \pm 0.07^{\mathrm{a}}$ & $3.19 \pm 0.07^{\mathrm{b}}$ & $3.17 \pm 0.07^{\mathrm{b}}$ \\
\hline $3^{\text {th }}$ and more & 84 & $2.36 \pm 0.04^{\mathrm{a} ; \mathrm{B}}$ & $2.40 \pm 0.04^{\mathrm{a} ; \mathrm{B}}$ & $3.28 \pm 0.05^{\mathrm{b}}$ & $3.21 \pm 0.05^{\mathrm{c}}$ \\
\hline
\end{tabular}

a, b, $c$ - means in the row with different superscripts differed significantly $(P<0.05)$

A, B - means in the column with different superscripts differed statistically significant $(P<0.05)$

TABLE 3. Quarter average milk flow rate of different lactation cows'

\begin{tabular}{l|l|l|l|l|l}
\hline \multirow{2}{*}{ Lactation number } & \multirow{2}{*}{$\begin{array}{l}\text { Number of } \\
\text { cows }\end{array}$} & \multicolumn{4}{l}{ Average flow rate of quarters, $\mathrm{kg} / \mathrm{min}$} \\
\cline { 3 - 6 } & & LF & RF & LR & RR \\
\hline 1 & 78 & $0.78 \pm 0.02^{\mathrm{a}}$ & $0.77 \pm 0.02^{\mathrm{a}}$ & $0.84 \pm 0.02^{\mathrm{a}}$ & $0.86 \pm 0.02^{\mathrm{a}}$ \\
\hline 2 & 67 & $0.93 \pm 0.03^{\mathrm{b}}$ & $0.97 \pm 0.03^{\mathrm{b}}$ & $1.06 \pm 0.03^{\mathrm{b}}$ & $1.04 \pm 0.03^{\mathrm{b}}$ \\
\hline $3^{\text {th }}$ and more & 84 & $0.91 \pm 0.02^{\mathrm{b}}$ & $0.99 \pm 0.02^{\mathrm{b}}$ & $1.03 \pm 0.02^{\mathrm{b}}$ & $1.05 \pm 0.02^{\mathrm{b}}$ \\
\hline
\end{tabular}

a, b, c - means in the column with different superscripts differed significantly $(P<0.05)$

The most milk flow characteristics were influenced by the lactation number. More cows had a decreased peak milk flow rates as the lactation progressed because of the reduced milk production and less persistence (Sandrucci et al., 2007). The average milk flow data of different lactation cows is presented in Table 3. The average milk flow in all cows was $0.96 \mathrm{~kg} / \mathrm{min}$. Compared to the average milk flow among the front and the rear quarters, a
$0.08 \mathrm{~kg} / \mathrm{min}$ lower flow was found in the front quarters $(\mathrm{P}<0.05)$. The average flow rate in $L F$ quarter was $0.05 \mathrm{~kg} /$ min lower than in RF and respectively 0.11 and $0.12 \mathrm{~kg} / \mathrm{min}$ lower than in LR and RR udder quarters $(P<0.05)$. Tancin et al. (2006) noticed that rear quarters had a significantly higher milk yield, longer time of milking, higher peak, and higher average flow rates than the front quarters. There were also differences in the measured flow rates 
between the left and the right quarters in comparison to the respective front or rear positions. The measured characteristics reported in study Tancin et al. (2002) are important in setting the default parameters in automated milking systems.

The smallest differences in the mean milk flow between the different quarters were found in the cows of first lactation. The average milk flow in single quarters of these cows was significantly lower than that of the second and third or more lactation cows $(P<0.05)$. Analysis of different lactation cows showed that with increasing the lactation number, the average milk flow increased too. The lowest average milk flow rate was established in the LF quarter of first lactation cows $(0.78 \mathrm{~kg} / \mathrm{min})$ and the highest in the LR quarter of the second lactation cows (1.06 kg/min). Sandruci et al. (2007) reported the most milk flow characteristics were influenced by the lactation number.

The peak milk flow data of in separate quarters of all cows is presented in Table 4. The highest milk flow in the front quarters was lower on average $0.11 \mathrm{~kg} / \mathrm{min}$ compared to that in the rear udder quarters $(P<0.05)$. The peak milk flow rate in $L F$ quarter was less on average by $0.09 \mathrm{~kg} / \mathrm{min}$ compared to that in the RF quarter, and correspondingly $0.16 \mathrm{~kg} / \mathrm{min}$ and $0.17 \mathrm{~kg} / \mathrm{min}$ less than in LR and RR quarters $(\mathrm{P}<0.05)$.

TABLE 4. Quarter peak flow rate $(\mathrm{kg} / \mathrm{min})$ according to the lactation number and th number of cows

\begin{tabular}{l|l|l|l|l|l}
\hline \multirow{2}{*}{ Lactation number } & \multirow{2}{*}{$\begin{array}{l}\text { Number of } \\
\text { cows }\end{array}$} & \multicolumn{4}{l}{ Peak flow rate of quarters, $\mathrm{kg} / \mathrm{min}$} \\
\cline { 3 - 6 } & & LF & RF & LR & RR \\
\hline 1 & 78 & $1.14 \pm 0.03^{\mathrm{a}}$ & $1.13 \pm 0.03^{\mathrm{a}}$ & $1.26 \pm 0.03^{\mathrm{a}}$ & $1.28 \pm 0.03^{\mathrm{a}}$ \\
\hline 2 & 67 & $1.32 \pm 0.03^{\mathrm{b}}$ & $1.45 \pm 0.05^{\mathrm{b}}$ & $1.50 \pm 0.04^{\mathrm{b}}$ & $1.49 \pm 0.04^{\mathrm{b}}$ \\
\hline $3^{\text {th }}$ and more & 84 & $1.32 \pm 0.03^{\mathrm{b}}$ & $1.47 \pm 0.03^{\mathrm{b}}$ & $1.49 \pm 0.02^{\mathrm{b}}$ & $1.51 \pm 0.02^{\mathrm{b}}$ \\
\hline
\end{tabular}

a, b, $c$ - means in the row with different superscripts differed significantly $(P<0.05)$

The highest milk flow rate in the first lactation cows per quarter was significantly lower than that of the other analysed lactation cows $(P<0.05)$. For the first lactation cows was determined the lowest difference of peak milk flow between separate quarters. In the front and the rear quarters the difference was respectively $0.01 \mathrm{~kg} / \mathrm{min}$ and $0.02 \mathrm{~kg} /$ min, while it varied at a level of $0.01 \mathrm{~kg} / \mathrm{min}$ and $0.02 \mathrm{~kg} / \mathrm{min}$. In the second, third and more lactation cows the largest milk flow fluctuations significantly differed in all quarters compared to the first lactation cows. A particularly clear difference was observed between the first and the third or more lactating cows. According to Grindal and Hillerton (1991) cows with a high peak flow rate are more sensitive to mastitis. The highest average maxi- mum milk flow rate was determined in dairy cows at the second lactation $(3.45 \pm 0.75 \mathrm{~kg} / \mathrm{min})$, while the lowest value was measured again in the group of dairy cows at the first lactation $(2.58 \pm 0.82 \mathrm{~kg} /$ min). The occurrence of bimodality was the highest in the group of dairy cows at the second lactation (45.45\%) (Strapak et al., 2009; Antalik et al., 2010).

Electrical conductivity of milk was correlated with the somatic cell count, so this parameter could be regarded as effective for diagnosing the health status of the udder. Electrical conductivity of milk was significantly lower $(\mathrm{P}<0.05)$ in all quarters of the first lactation cows' milk than in more lactations cows, except the RF udder quarter of the second lactation cows (Table 5).

TABLE 5. Electrical conductivity (mS/cm) of cow's milk from different quarters (LF, RF, LR, RR) of different lactation cows'

\begin{tabular}{|c|c|c|c|c|c|}
\hline \multirow[t]{2}{*}{ Lactation number } & \multirow{2}{*}{$\begin{array}{l}\text { Number } \\
\text { of cows }\end{array}$} & \multicolumn{4}{|c|}{ Electrical conductivity in udder quarters, $\mathrm{mS} / \mathrm{cm}$} \\
\hline & & LF & RF & LR & $\mathrm{RR}$ \\
\hline 1 & 78 & $4.26 \pm 0.04^{a}$ & $2.71 \pm 0.21^{a}$ & $4.27 \pm 0.04^{a}$ & $2.61 \pm 0.21^{a}$ \\
\hline 2 & 67 & $4.48 \pm 0.04^{b}$ & $2.98 \pm 0.22^{a}$ & $4.49 \pm 0.04^{b}$ & $3.19 \pm 0.20^{b}$ \\
\hline $3^{\text {th }}$ and more & 84 & $4.59 \pm 0.03^{c}$ & $3.77 \pm 0.11^{b}$ & $4.54 \pm 0.03^{b}$ & $3.67 \pm 0.10^{c}$ \\
\hline
\end{tabular}

a, b, c - means in the column with different superscripts differed statistically significant $(P<0.05)$ 
TABLE 6. Correlations among the analysed indicators and the udder quarters by cows' lactation

\begin{tabular}{|c|c|c|c|c|c|c|c|c|c|c|}
\hline & & \multicolumn{9}{|c|}{ Lactation number } \\
\hline & & \multicolumn{3}{|c|}{$1^{\text {th }}$} & \multicolumn{3}{|c|}{$2^{\text {th }}$} & \multicolumn{3}{|c|}{$3^{\text {th }}$ and more } \\
\hline & & $\mathrm{RF}$ & LR & $\mathrm{RR}$ & $\mathrm{RF}$ & LR & $\mathrm{RR}$ & $\mathrm{RF}$ & LR & $\mathrm{RR}$ \\
\hline \multirow[t]{3}{*}{ Milk yield, kg } & LF & $0.772^{* * *}$ & $0.426^{\star * \star}$ & $0.571^{* * *}$ & $0.695^{* * *}$ & $0.342^{* * *}$ & 0.123 & $0.567^{* \star *}$ & $0.411^{* * \star}$ & $0.373^{* \star \star}$ \\
\hline & $\mathrm{RF}$ & & $0.459^{* * *}$ & $0.520^{* * *}$ & & $0.417^{* * *}$ & 0.128 & & $0.268^{* * *}$ & $0.353^{* \star *}$ \\
\hline & LR & & & $0.597^{* \pm *}$ & & & $0.470^{* \star \star}$ & & & $0.640^{* \star \star}$ \\
\hline \multirow{3}{*}{$\begin{array}{l}\text { Average milk flow, } \\
\text { kg/min }\end{array}$} & LF & $0.725^{* * *}$ & $0.537^{* * *}$ & $0.513^{* * *}$ & $0.656^{* * *}$ & $0.628^{* * *}$ & $0.449^{* * *}$ & $0.762^{* * *}$ & $0.722^{* * *}$ & $0.674^{* * *}$ \\
\hline & $\mathrm{RF}$ & & $0.566^{* * *}$ & $0.425^{* * *}$ & & $0.520^{* * *}$ & $0.427^{* * *}$ & & $0.684^{* * *}$ & $0.659^{* * *}$ \\
\hline & LR & & & $0.756^{* * *}$ & & & $0.687^{* * *}$ & & & $0.806^{* \star *}$ \\
\hline \multirow{3}{*}{$\begin{array}{l}\text { Peak flow rate, kg/ } \\
\text { min }\end{array}$} & LF & $0.641^{* * *}$ & $0.532^{* * *}$ & $0.448^{* * *}$ & $0.588^{* * *}$ & $0.555^{* * *}$ & $0.484^{* * *}$ & $0.695^{* * *}$ & $0.668^{* * *}$ & $0.633^{* * *}$ \\
\hline & $\mathrm{RF}$ & & $0.462^{* * *}$ & $0.318^{* * *}$ & & $0.424^{* * *}$ & $0.457^{* * *}$ & & $0.591^{* * *}$ & $0.614^{* * *}$ \\
\hline & LR & & & $0.656^{* * *}$ & & & $0.639^{* * *}$ & & & $0.759^{* * *}$ \\
\hline \multirow{3}{*}{$\begin{array}{l}\text { Milking duration, } \\
\text { min }\end{array}$} & LF & $0.768^{* * *}$ & $0.632^{* * *}$ & $0.714^{* * *}$ & $0.679^{* * *}$ & $0.482^{* * *}$ & $0.584^{* * *}$ & $0.761^{* * *}$ & $0.698^{* * *}$ & $0.685^{* * *}$ \\
\hline & $\mathrm{RF}$ & & $0.635^{* * *}$ & $0.743^{* * *}$ & & $0.555^{* * *}$ & $0.594^{* * \star}$ & & $0.581^{* \star *}$ & $0.641^{* * *}$ \\
\hline & LR & & & $0.699^{* * *}$ & & & $0.675^{* \star *}$ & & & $0.780^{* \star \star}$ \\
\hline \multirow{3}{*}{$\begin{array}{l}\text { Electrical } \\
\text { conductivity, } \\
\mathrm{mS} / \mathrm{cm}\end{array}$} & LF & $0.420^{* * *}$ & $0.882^{* * *}$ & -0.051 & $0.459^{* * *}$ & $0.771^{* * *}$ & 0.025 & $0.253^{* * *}$ & $0.572^{* * \star}$ & $0.154^{* *}$ \\
\hline & $\mathrm{RF}$ & & $0.350^{* * *}$ & $-0.577^{* \star *}$ & & $0.416^{* * *}$ & $-0.361^{* * *}$ & & 0.237 & $-0.166^{* *}$ \\
\hline & LR & & & -0.046 & & & 0.106 & & & $0.131^{*}$ \\
\hline
\end{tabular}

${ }^{*} \mathrm{P}<0.05 ;{ }^{* *} \mathrm{P}<0.1 ;{ }^{* * *} \mathrm{P}<0.001$

The difference in electrical conductivity between the RF and the RR quarters of the first and the second lactation cows was $0.10 \mathrm{mS} / \mathrm{cm}$. Meanwhile the in electrical conductivity between the LF and the LR quarters in the second lactation cows differed fractionally $(0.01 \mathrm{mS} / \mathrm{cm})$ but it was 0.21 $\mathrm{mS} / \mathrm{cm}$ between RF and RR quarters. Electrical conductivity between the RF and the RR quarters of the third and more lactating cows was $1.06 \mathrm{mS} /$ $\mathrm{cm}$ higher in comparison to the adequate quarters of the first lactation cows $(\mathrm{P}<0.05)$. It was reported that the electrical conductivity of $5.5 \mathrm{mS} / \mathrm{cm}$ in milk was a threshold for the subclinical mastitis (Mammadova et al., 2013). Other researches reported that the electrical conductivity of milk ranged from 4.6 to $5.8 \mathrm{mS} / \mathrm{cm}$ in samples with somatic cell counts below $200.000 / \mathrm{mL}$ and variation in electrical conductivity of milk could be accepted as one of the key parameters in the milking system for health monitoring system of dairy cows (Juozaitienè et al., 2015). According to the obtained results, electrical conductivity of milk ranged from 2.62 to $4.59 \mathrm{mS} / \mathrm{cm}$ so it could be presumed that the somatic cell count did not exceed $200.000 / \mathrm{mL}$.

Correlations among the analysed indicators and udder quarters by cows' lactation are presented in Table 6. Milk yield in separate udder quarters in dairy cows were found to positively correlate. The highest correlation was observed between LF and RF (from 0.567 in the third lactation to 0.7772 in the first lactation, $\mathrm{P}<0.001$ ) and $L R$ with $R R$ (from 0.470 in the second lactation to 0.640 in the third lactation, $\mathrm{P}<0.001)$. After evaluating the correlation between the milk content in one quarter and the other quarters, similar correlations (0.476 to $0.7797, P<0.001)$ were found in all lactations. Both, the average milk flow and the peak milk flow from different udder quarters were positively correlated to the average strength. The weakest but statistically significant intermediate-strength relationships were obtained in all lactations for the RR and front quarters LF (from 0.449 to 0.6474 respectively in second and in third lactation) and RF (0.427 in the second lactation to 0.659 in the third lactation). The strongest correlation (0.656 - to 0.806) in all lactations were established between the front (LF with RF) and the rear (LR with RR) quarters. The quarters according to the peak milk flow were also distributed. Evaluating the relation of the highest and the average milk flow in one quarter with other quarters together were established, strong positive correlations (from 0.0620 to $0.803, P<0.001$ ) were found in all lactations. The correlation between the milking duration from different quarters in dairy cows was very similar and ranged from positive average strength (0.555 in second lactation RF with LR quarters) to positive strong (0.780 in third and more lactations 
LR with RR). There was a strong correlation (from 0.701 to $0.860 ; \mathrm{P}<0,001$ ) between the milking duration from one quarter and the duration from other quarters together. The largest differences were fixed after evaluating associations between milk electrical conductivity among different udder quarters. A negative correlation was found in dairy cows between the RF and the RR quarters and it ranged from -0.166 in the third and more lactations to -0.577 in the first lactation. Meanwhile, on the left side positive correlations (from 0.572 in the third and more to 0.882 in the first lactation) were observed. In the rear udder quarters statistically insignificant close to zero correlations were found between the LR and the FR in all lactations, while the correlations between the LF and the RF quarters were statistically significant (from 0.253 to 0.459). According to Sandruci et al. (2007) milk yield per milking was positively related to the peak milk flow rate $(r=0.33 ; P<0.001)$ and the total milking time $(r=0.47 ; P<0.001)$.

\section{Conclusions}

First lactation cows showed a lower milk production per milking in all udder quarters in comparison to other lactation cows $(P<0.05)$. The duration of milking of the third and more lactation cows in front quarters was shorter than that of the first lactation cows $(\mathrm{P}<0.005)$. As the number of lactations increased, the milking time in the front quarters decreased. The average milk flow and the peak flow in the first lactation cows were found to be lower than that in older cows $(\mathrm{P}<0.05)$.

\section{Muzni parametri u ovisnosti o četvrti vimena i broju laktacija muznih krava}

\section{Sažetak}

Ova studija provedena je na 229 muznih krava u Litvi, a za mužnju korišteni su roboti tvrte DeLaval. Pritom su u svakoj pojedinoj četvrti vimena, ovisno o broju laktacija određivani prinos mlijeka (kg), trajanje mužnje (min), protok mlijeka (kg/min) i najviše vrijednosti protoka (kg/min). Statistička analiza prikupljenih podatka napravljena je pomoću programskog paketa Statistical Package for Social Science 22 za Windows, Kolmogorov-Smirnovog testa i modela analize varijance s jednim utjecajnim faktorom (ANOVA). Raspodjela četvrti vimena vrlo je važna u postupku mužnje. Prinos mlijeka u prednjim četvrtima vimena iznosio je oko 4,6 kg (42,2 \%), a u zadnjim 6,32 kg (57,8 \%) (P<0,05). Dakle, količina mlijeka bila je značajno manja $(P<0,05)$ u prednjim četvrtima vimena u svih ispitivanih muznih krava. Uzimajući u obzir proizvodnju mlijeka u svim četvrtima vimena, mliječnost krava u prvoj laktaciji značajno je manja $(\mathrm{P}<0,05) \mathrm{u}$ odnosu na krave s većim brojem laktacija. Trajanje mužnje prednjih četvrti vimena krava u trećoj i višoj laktaciji bilo je kraće nego u krava u prvoj laktaciji $(\mathrm{P}<0,005)$. S porastom broja laktacija opadalo je trajanje mužnje u prednjim četvrtima. Prosječan protok mlijeka i njegova maksimalna vrijednost bili su niži kod krava u prvoj laktaciju u odnosu na starije krave $(\mathrm{P}<0,05)$.

\section{Ključne riječi: strojna mužnja, krava, laktacija, vime, četvrt}


1. Antalik, P., Strapak, P. (2010): The evaluation of milkability of Slovak Pinzgau cattle by lactocorder. Slovak Journal of Animal Science 43 (4), 173-178.

2. Arbel, R., Bigun, Y., Ezra, E., Sturman, H., Hojman, D. (2001): The effect of extended calving intervals in high lactating cows on milk production and profitability. Journal of Dairy Science 84, 600-608. https://doi.org/10.3168/jds.S0022-0302(01)74513-4

3. Bach, A., Busto, I. (2005): Effects on milk yield of milking interval regularity and teat cup attachment failures with robotic milking systems. Journal of Dairy Research 72, 101-106.

4. Berglund, I., Pettersson, G., Östensson, K., SvennerstenSjaunja, K. (2007): Quarter Milking for Improved Detection of Increased SCC. Reproduction in Domestic Animals 42, 427-432. https://doi.org/10.1111/j.1439-0531.2006.00803.

5. Castro, A., Pereira, J.M., Amiama, C., Bueno, J. (2012): Estimating efficiency in automatic milking systems. Journal of Dairy Science 95, 929-936. https://doi.org/10.3168/jds.2010-3912.

6. Grindal, R.J., Hillerton, J.E. (1991): Influence of milk flow rate on new intramammary infection in dairy cows. Journal of Dairy Research 58 (3), 263-268.

7. Ipema, A.H., Hogewerf, P.H. (2008): Quarter-controlled milking in dairy cows. computers and electronics in agriculture 62, 59-66. https://doi.org/10.1016/j.compag.2007.09.007.

8. Jacobs, J.A., Siegford, J.M. (2012): Invited review: The impact of automatic milking systems on dairy cow management, behavior, health, and welfare. Journal of Dairy Science 95, 2227-47. https://doi.org/10.3168/jds.2011-4943

9. Juozaitienè, V., Juozaitis, A., Brazauskas, A., Žymantienè, J., Žilaitis, V., Antanaitis, R., Stankevičius, R., Bobinienè, R. (2015): Journal of Measurements in Engineering 3, 63-70.

10. Kaihilahti, J., Suokannas, A., Raussi, S. (2007): Observation of cow behaviour in an automatic milking system using web-based video recording technology. Biosystems Engineering 96, 1, 91-97. https://10.1016/j.biosystemseng.2006.10.001

11. Lee, D. H., Choudhary, V. (2006): Study on Milkability traits in Holstein cows. Asian-Australasian Journal of Animal Science 19, 309-314. https://doi.org/10.5713/ajas.2006.309

12. Mammadova, N., Keskin, i. (2013): Application of the support vector machine to predict subclinical mastitis in dairy cattle. The Scientific World Journal. http://dx.doi.org/10.1155/2013/603897

13. Pastell, M., Takko, H. Gröhn, H., Hautala, M., Poikalainen, V., Praks, J., Veermae, I., Kujala, M., Ahokas, J. (2006): Assessing cows' welfare: weighing the cow in a milking robot. Biosystems Engineering 93 (1), 81-87. https://doi.org/10.1016/j.biosystemseng.2005.09.009

14. Ray, D.E., Halbach, T.J., Armstrong, D.V. (1992): Season and lactation number effects on milk production and reproduction of dairy cattle in Arizona. Journal of Dairy Science 75, 2976-2983.
15. Sandrucci, A., Tamburini, A., Bava, L., Zucali, M. (2007): Factors affecting milk flow traits in dairy cows: results of a field study. Journal of Dairy Science 90, 1159-67. https://doi.org/10.3168/jds.S0022-0302(07)71602-8.

16. Schukken, Y.H., Wilson, D.J., Welcome, F., Garrison-Tikofsky, L., Gonzalez, R.N. (2003): Monitoring udder health and milk quality using somatic cell counts. Veterinary Researches 34, 579-596. https://doi.org/10.1051/vetres:2003028

17. Sitkowska, B., Piwczynski, D., Aerts, J., Waskowicz, M. (2015): Changes in milking parameters with robotic milking. Archives Animal Breeding 58, 137-143. https://doi:10.5194/aab-58-137-2015.

18. Slyžius, E., Juozaitiene, V., Juozaitis, A., Zilaitis, V., Slyziene, B., Cereskiene, E. (2014): Udder quarters morphological and milking traits risk factors influencing productivity and subclinical mastitis in dairy cows. Bulgarian Journal of Agricultural Science 20 (6), 1502-1507.

19. Strapak., P., Sukenikova, Z., Antalik, P. (2009): Milkability in Holstein cows. Journal of Central European Agriculture 10, 207-210.

20. Tancin, V., Ipema, B., Hogewerf, P., Groot Koerkamp, P., Mihina, S., Bruckmaier, R. M. (2002): Milk flow patterns at the end of milking analysed on the udder or quarter levels: relationship to somatic cell count. Milk Science International 57, 306-309.

21. Tancin, V., Ipema, A.H., Peskovicova, D., Hogewerf, P.H., Macuhova, J. (2003): Quarter milk flow patterns in dairy cows: Factors involved and repeatability. Veterinarni Medicina 48 (10), 275-282. https://doi.org/10.17221/5780-VETMED.

22. Tancin, V., Ipema, B., Hogewerf, P., Macuhová, J. (2006): Sources of variation in milk flow characteristics at udder and quarter levels. Journal of Dairy Science 89 (3), 978-988. https://doi.org/10.3168/jds.S0022-0302(06)72163-4.

23. Tancin, V., Uhrincat, M., Macuhova, L., Bruckmaier, R.M. (2007a): Effect of pre-stimulation on milk flow pattern and distribution of milk constituents at a quarter levels. Czech Journal of Animal Science 52, 117-121.

24. Tancin, V., Uhrincat, M., Mihina, J., Sudzinova, J., Foltys, V., Tancinova, D. (2007b): Somatic cell count and quarter milk flow parameters from udder of dairy cows. Slovakian Journal of Animal Science 40 (2), 79-82.

25. Vijayakumar, M., Park, J.H., Ki, Ks., Lim, D.H., Kim, S.B., Park, S.M., Jeong, H.Y., Park, B.Y., Kim, T.I. (2017): The effect of lactation number, stage, length, and milking frequency on milk yield in Korean Holstein dairy cows using automatic milking system. Asian-Australasian Journal of Animal Science 30 (8), 1093-1098.

https://doi.org/10.5713/ajas.16.0882

26. Weiss, D., Weinfurtner, M., Bruckmaier, R.M. (2004): Teat anatomy and its relationship with quarter and udder milk flow characteristics in dairy cows. Journal of Dairy Science 87, 3280-3289. 